\title{
多径間ラーメン隅角部の応力分布とその近似計算
}

\author{
正員山本 稔* \\ 正員井上広胤**
}

\section{STRESS DISTRIBUTION AND ITS CALCULATION IN CORNER OF RIGID-FRAME STRUCTURE WITH MANY PANELS}

\section{By Minoru Yamamoto, C.E. Member and Hirotane Inoue, C.E. Member}

Synopsis: By the two dimentional photo-elastic experiments of $\mathrm{Y}$ - and $\mathrm{T}$-type corners of rigid-frame structure, the authors were able to make clear the stress distribution in the sections which are important on the design of the corners. They commented on the approximate calculation which has been hitherto used and proposed its improved method.

要旨 $\mathrm{Y}$ 型扔よび $\mathrm{T}$ 型ラーメン隅角部の二次元光弾性実験沉よつて, 設計上重要な断面の応力分布状 態を明確にした。更にこの結果にもとついて従来使用されてきた近似計算法を批判し，その改良策につ いて提案した。

\section{1. 緒言}

多径間ラーメンの中間節点の隅角部は $\mathrm{Y}$ 型または $\mathrm{T}$ 型の隅角部である。な招フィレンデール桁節点も $\mathrm{T}$ 型ラー メン隅角部と同じ形状をなすからこの中に包含して考劣ることができる。これらラーメン隅角部の近似計算法に

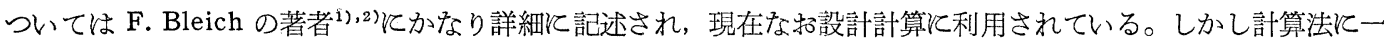
貫性がないばかりでなく公式の運用にあたつても不明確な点がある。そてで筆者は光弾性実験によつて応力分布 状龍を調べるとともに，從来の計算法を検討し更に進しで曲梁理論 ${ }^{3}$ とる近似計算法の合理性ととの運用法につ いて考察したいと思う。

\section{2. 実験とその結果}

テストピースの形状寸法は 図-1 と示すと括りで，Y型のテストピースには 図-2 の (a)(b)(c) の3 種の荷 重を, また T 型のそれとは (a) (b) の2 種の荷重を加兄て試験し写真のごとき等色線と等傾曲線を兄た。この等

図-1

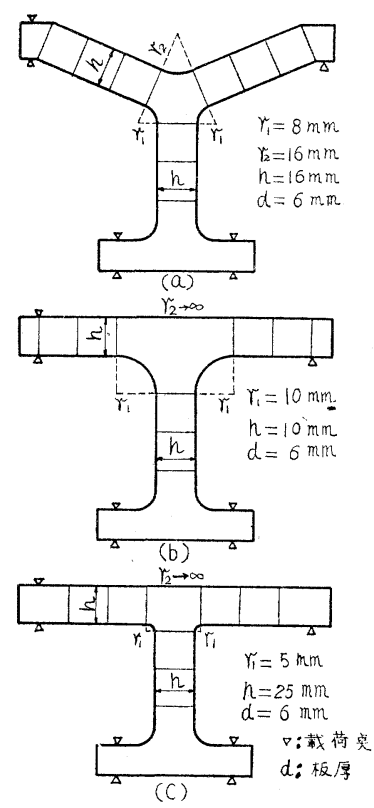

図-2

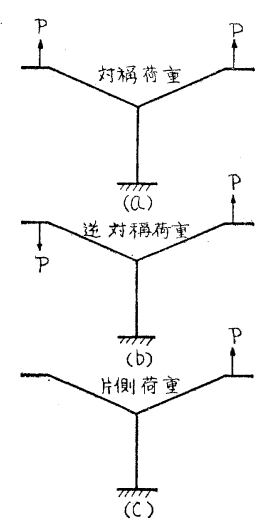


傾曲線は観測誤差をできるだけ少なくするため直接印画紙に撮影された陰画の二,三の例である。図一3はこのよ ろな等傾曲線を一まとめにしたもので等色線 写真一1 (b) 扣よび 写真一2（a）の試験に対応するものである。

対称抽よび逆対称荷重は設計上重要な断面の応力状態を明瞭観察するためと使用されたばかりでなく，これ を組合わせることによつて種々の荷重状態が党られるという便利さをるつている。片側荷重による実験は実験精 度を知る目安として行つたが，これはな拉笚独の L 型ラーメンの実験" と比較して，近似公式としての曲梁公式の 適合性を知るうえにやくだつた。

\section{図一-3（a） 写真一1 (b) に対応する等傾曲線および主応力線図}

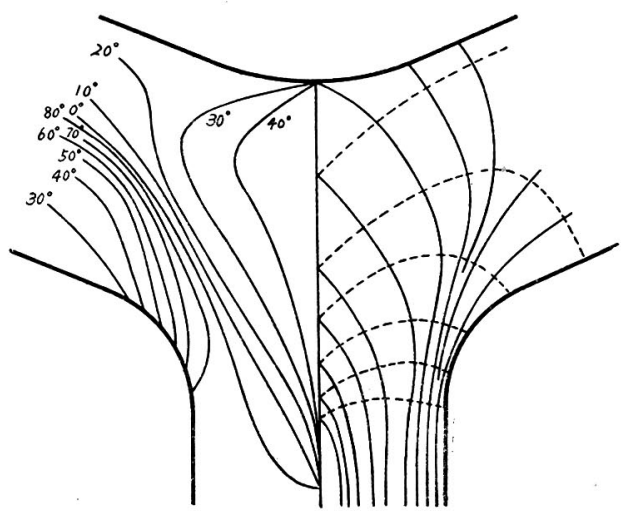

図一3 (b) 写真一2（a) に対応する等傾曲線およひ主応力線図

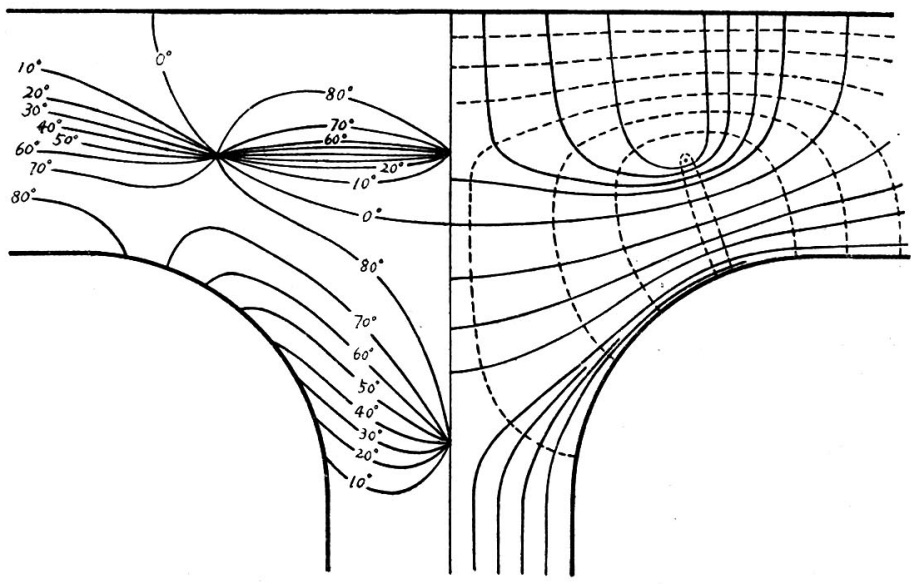

写真-1 (a) 対 称 荷 重

$P=7.83 \mathrm{~kg}$ フリンジ応力 $=10.35 \mathrm{~kg} / \mathrm{cm}$

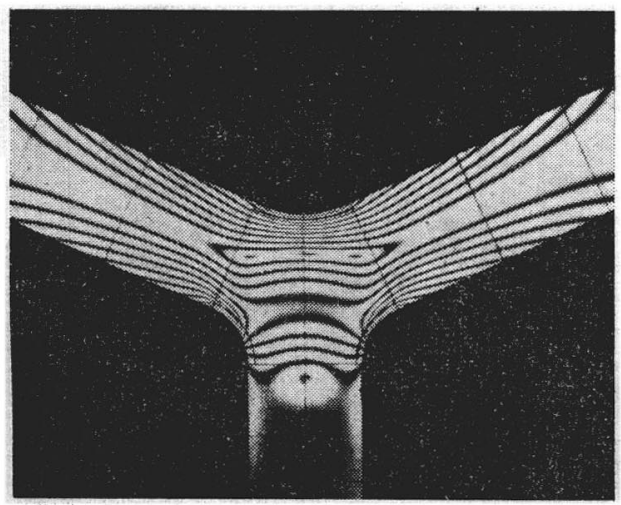

写真-1 (b) 逆対称荷重

$P=2.43 \mathrm{~kg}$ フリンジか $=10.35 \mathrm{~kg} / \mathrm{cm}$

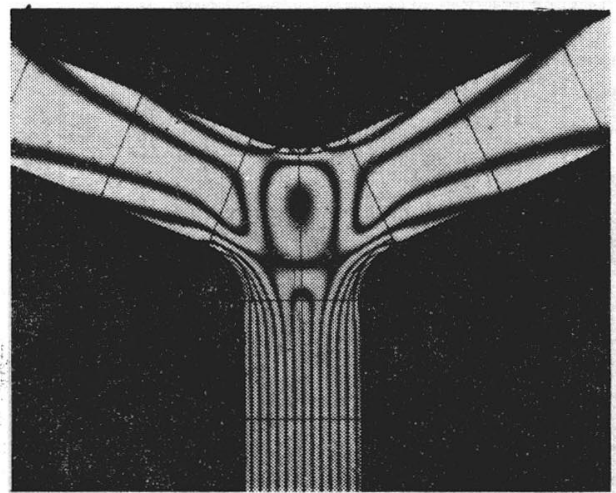


写真一1 (c) 片 側 荷 重

$P=5.02 \mathrm{~kg}$ フリンジ応力 $=10.35 \mathrm{~kg} / \mathrm{cm}$

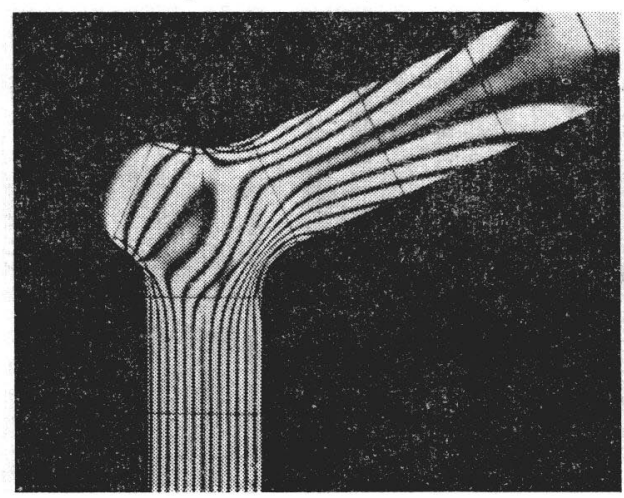

写真-2 (a)

$P=5.55 \mathrm{~kg}$ フリンジ応力 $=8.08 \mathrm{~kg} / \mathrm{cm}$

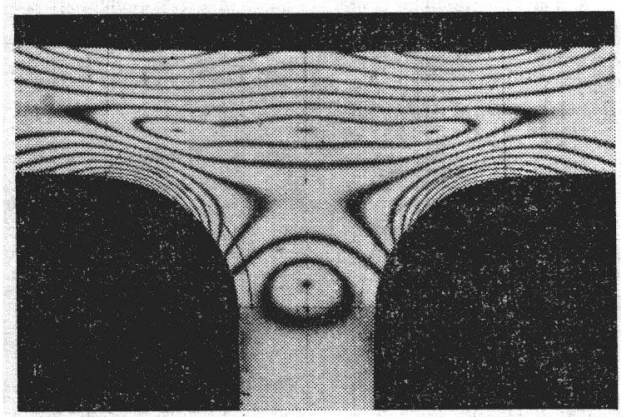

写真-3(a)

$P=6.43 \mathrm{~kg}$ フリンジ成力 $=8.02 \mathrm{~kg} / \mathrm{cm}$

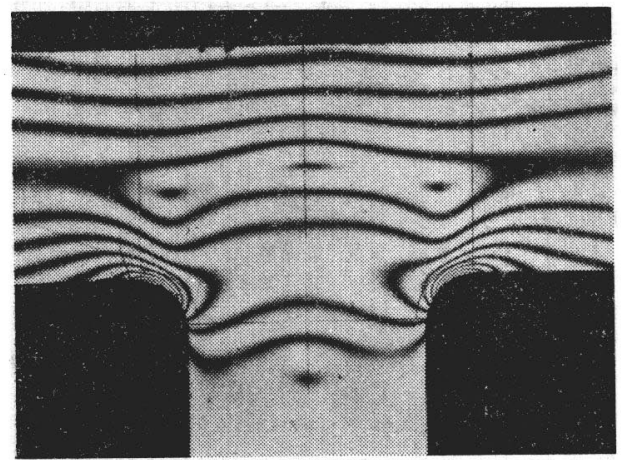

写真-2 (b)

$P=1.64 \mathrm{~kg}$ フリンジ応力 $=8.08 \mathrm{~kg} / \mathrm{cm}$

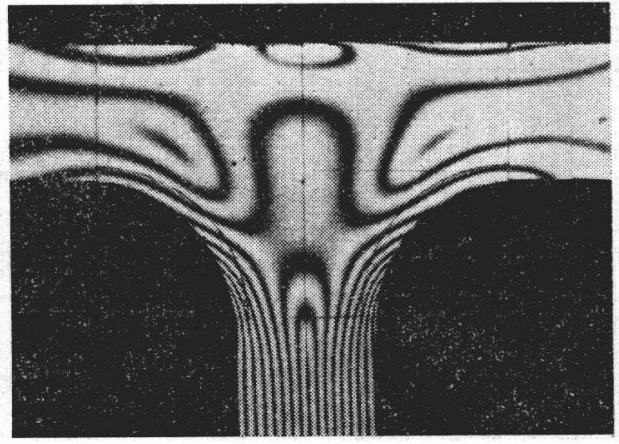

写真-3 (b)

$P=3.57 \mathrm{~kg}$ フリンジ応力 $=8.02 \mathrm{~kg} / \mathrm{cm}$

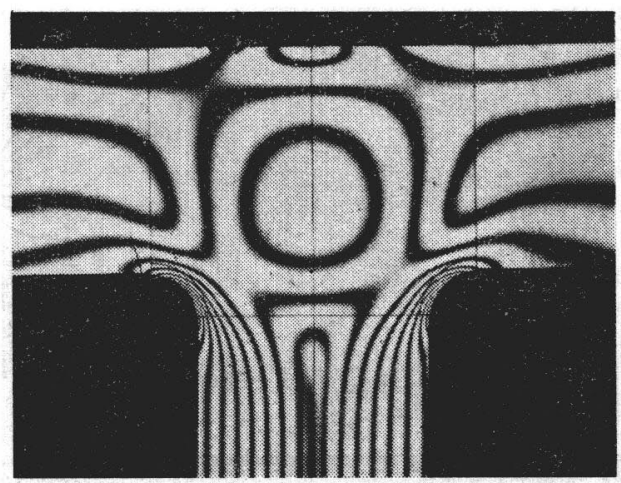

写真-4 (a) 写真一1 (b) に対応する等傾曲線

$0^{\circ}$

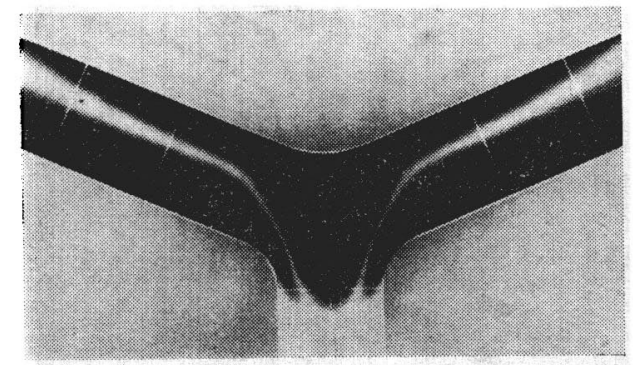

$45^{\circ}$

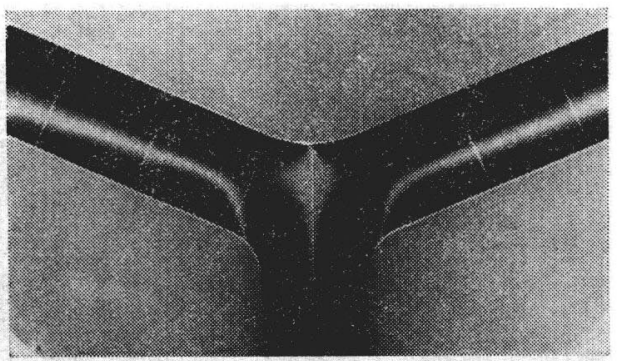


$0^{\circ}$

写真一4 (b) 写真一2 (a) に対応する等傾曲線
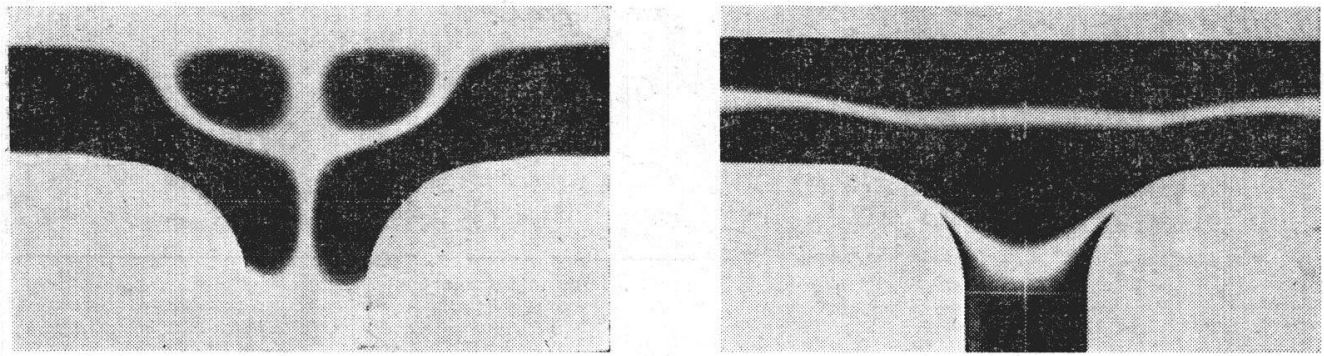

周辺応力の最大値は対称荷重のときには上側縁の中央めるいは左右側縁のハリと隅角部との接続点付近の隅角 部側に発生する。一方逆対称荷重括よび片側荷重のときには左右の側緑上で柱と隅角部との接続点付近の隅角部 側に生ずる。これら最大応力の発生点は $\boldsymbol{r} / \boldsymbol{h}$ が大きくなるにしたがつて接続点に近つくことは写真からうかがわ れるが、すでにし型ラーメンの実験いで諗められた事実である。おた縁応力が最大となる位置は設計上重要で近似 計算の対象となる断面を与觉る。

\section{3. 主要断面における応力分布}

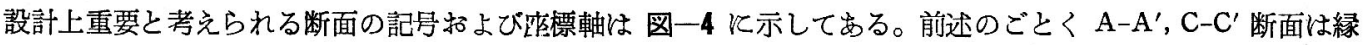
疬力が最大となりうる断面である。E-E' 断面は対称荷重で縁応力が大きな值をとることるあるし，また逆対称荷 重で最大セン断応力が生じる断面である。B-B', D-D' 断面は荷重の状態によつては大きい応力が発生するから検 算すべき断面である。これらの諸断面の态力解析は等色線と等傾曲線とから セン断応力差積分法を用いて行われた。自由周辺によつて限られた断面に括 いては応力の合力と外力とは釣合うことから 解析結果の 誤差を推定できる。 本実験に扔ける A-A'，C-C' 断面のこの誤差は $5 \%$ 以下であつた。また周辺 の応力はかなり精度よく求められるから 解析断面の延長上飞自由周迅が存在 する場合（例えぼ $\mathrm{B}_{2}-\mathrm{B}_{2}{ }^{\prime}$ 断面）とか応力值の明らかな点（例壳ば $\mathrm{E}-\mathrm{E}^{\prime}$ 断面 に対する C-C 断面の中央点) がある場合には解析をこれらの点まで実施し， 両者を較べて計算誤差の累積をできるだけ少なくするように心がけた。かく して党られた応力分布は $P=4 \mathrm{~kg}$ の場合に換算して図一5〜 凤示してある。 $\mathrm{A}_{3}-\mathrm{A}_{3}{ }^{\prime}, \mathrm{B}_{3}-\mathrm{B}_{3}{ }^{\prime}, \mathrm{C}_{2}-\mathrm{C}_{2}{ }^{\prime}$ 扣よび $\mathrm{D}-\mathrm{D}^{\prime}$ 断面の応力分布は他から類推できる

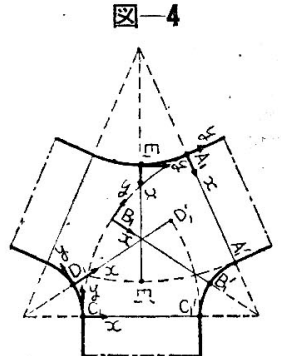

(a)

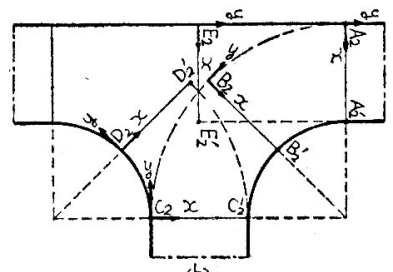

(b)

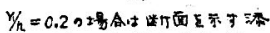

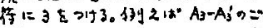
tl.

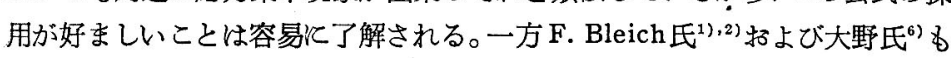
この隅角部の計算法にふれているが，それはかなり大䏣な仮定をしたりまた利用上明確さと欠けたりしている。 そこで実験值と比較してこれら計算法の精度を調べるとともに曲梁公式による筆者の近似計算法について述べる

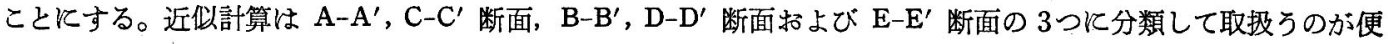
利である。

(1) A-A'，C-C' 断面 F. Bleich 氏抽よび大野氏はこれら接続断面については学にそれに接続する辺縁の半

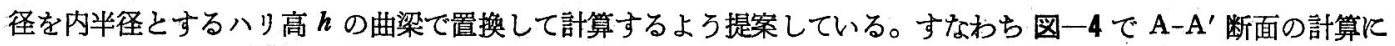
は $\mathrm{ABCC}^{\prime} \mathrm{B}^{\prime} \mathrm{A}^{\prime}$ または $\mathrm{AEE} \mathrm{A}^{\prime}$ なる扇形の曲梁に $\mathrm{A}-\mathrm{A}^{\prime}$ 断面の断面力が作用するとして計算するのである。しか しこの断面の応力は両側の辺縁の影響をうけるから合理的な計算法とはいえない。そこで筆者は断面力が $\mathrm{ABCC}$ $\mathrm{B}^{\prime} \mathrm{A}^{\prime}$ 括よび $\mathrm{AEE}^{\prime} \mathrm{A}^{\prime}$ なる 2 つの曲梁に分配されて作用するとの仮定のもとに上記の 3 種のラーメン隅角部抽よび 
図-5

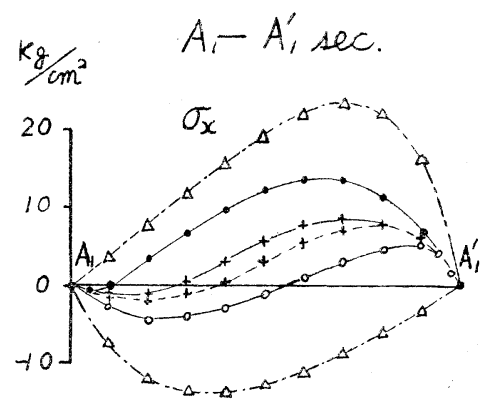

$$
A_{2}-A_{2}^{\prime} \text { sec. }
$$

$B_{1}-B_{1}^{\prime}$ sec.

$\mathrm{kg} / \mathrm{m}^{2}$

$\sigma_{x}$

$\mathrm{kg} / \mathrm{cm}^{2}$

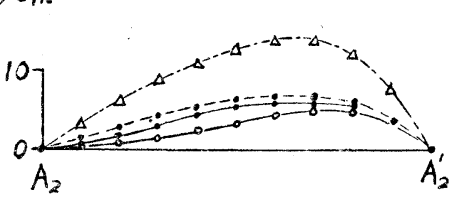

$\mathrm{kg} / \mathrm{m}^{2}$
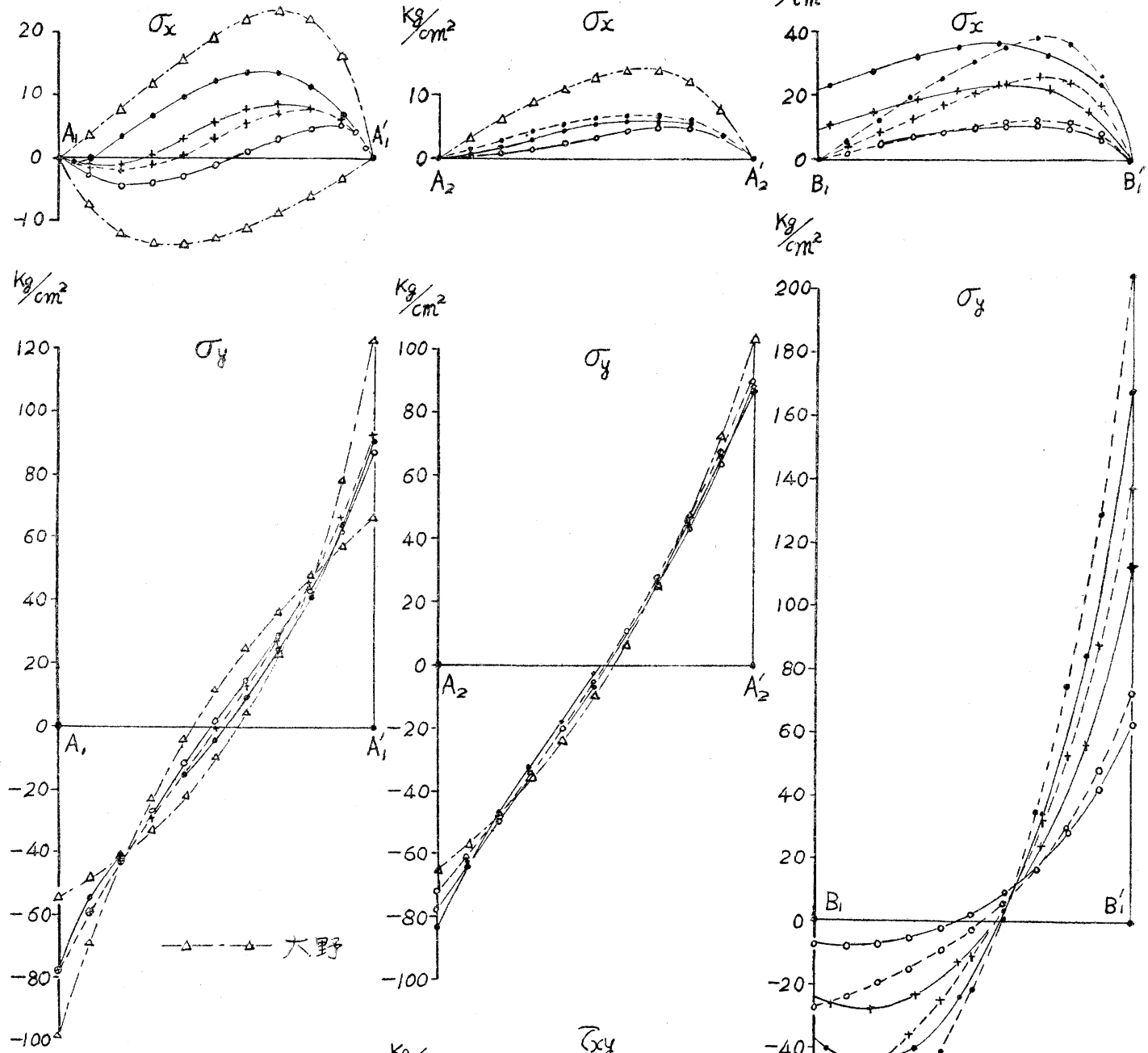

$\mathrm{kg} / \mathrm{cm}^{2}$

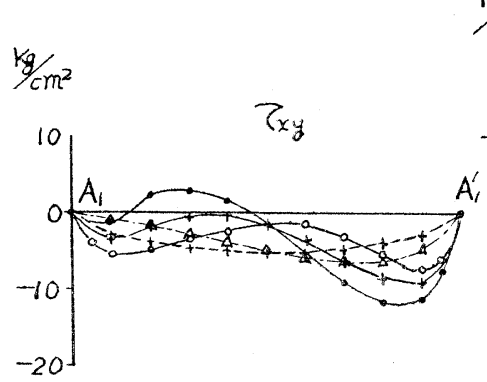

-0工一対称荷重(实験)

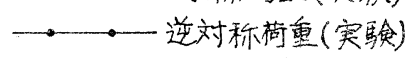

- - - - - - - 対标荷重 (計算)

$\tau x y$

$\mathrm{Kg} / \mathrm{cm}^{2}$

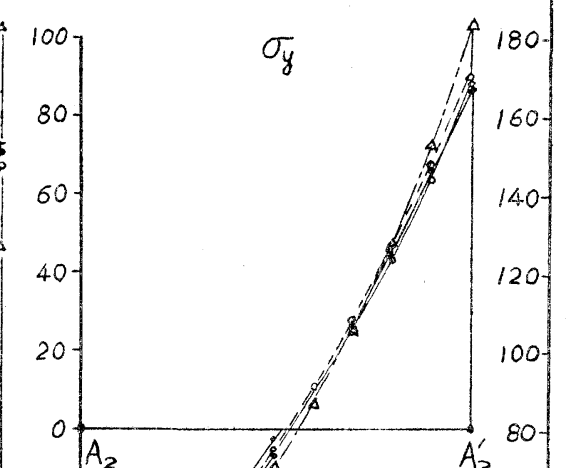

2007

$\sigma_{y}$

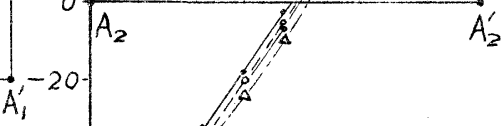

$A_{2}^{80}$
60

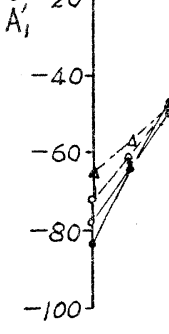

$A_{i}^{\prime}$

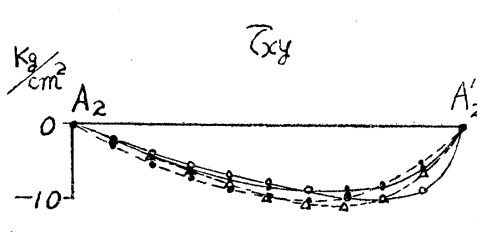

$\mathrm{A}_{2}^{\prime}$

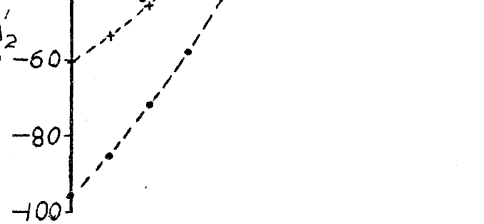

- + - - - - 片测荷重(实雅)

逆対称荷重(計算)

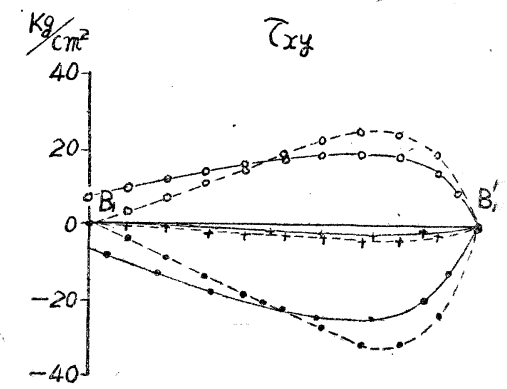




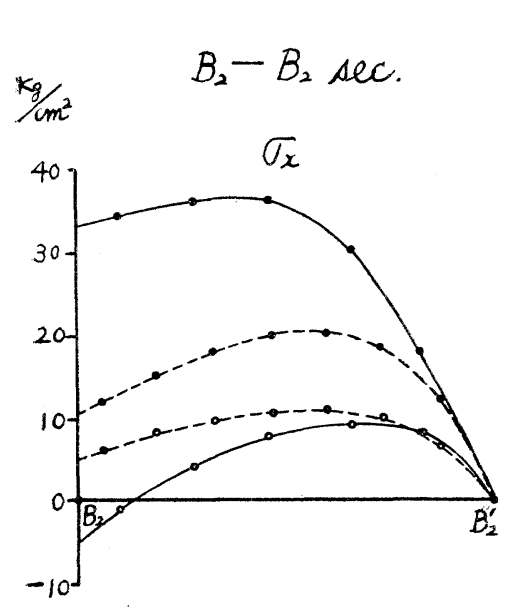

\section{図-6}

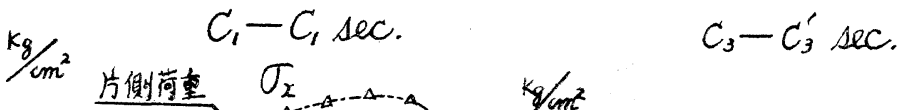
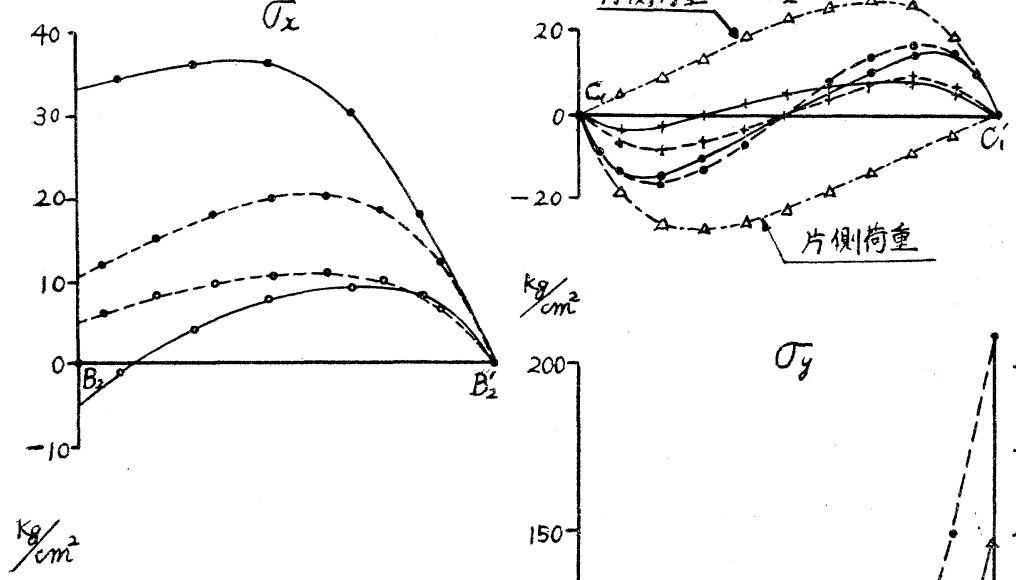

$\mathrm{kg} / \mathrm{cm}^{2}$

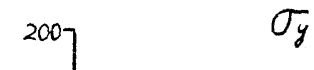

120

$\sigma_{y}$

\section{$100-100$}

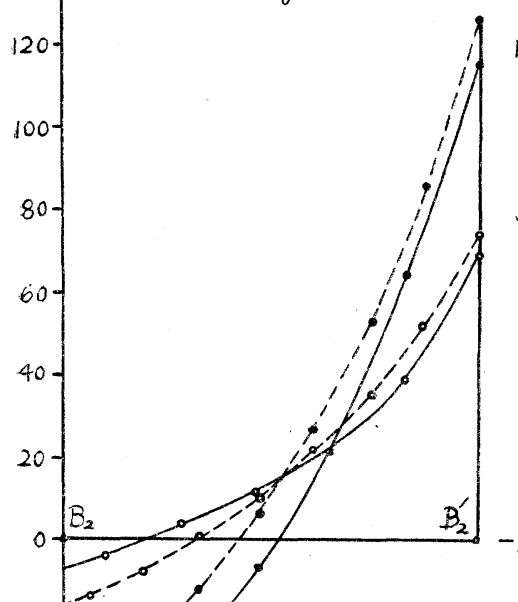

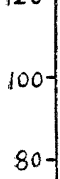
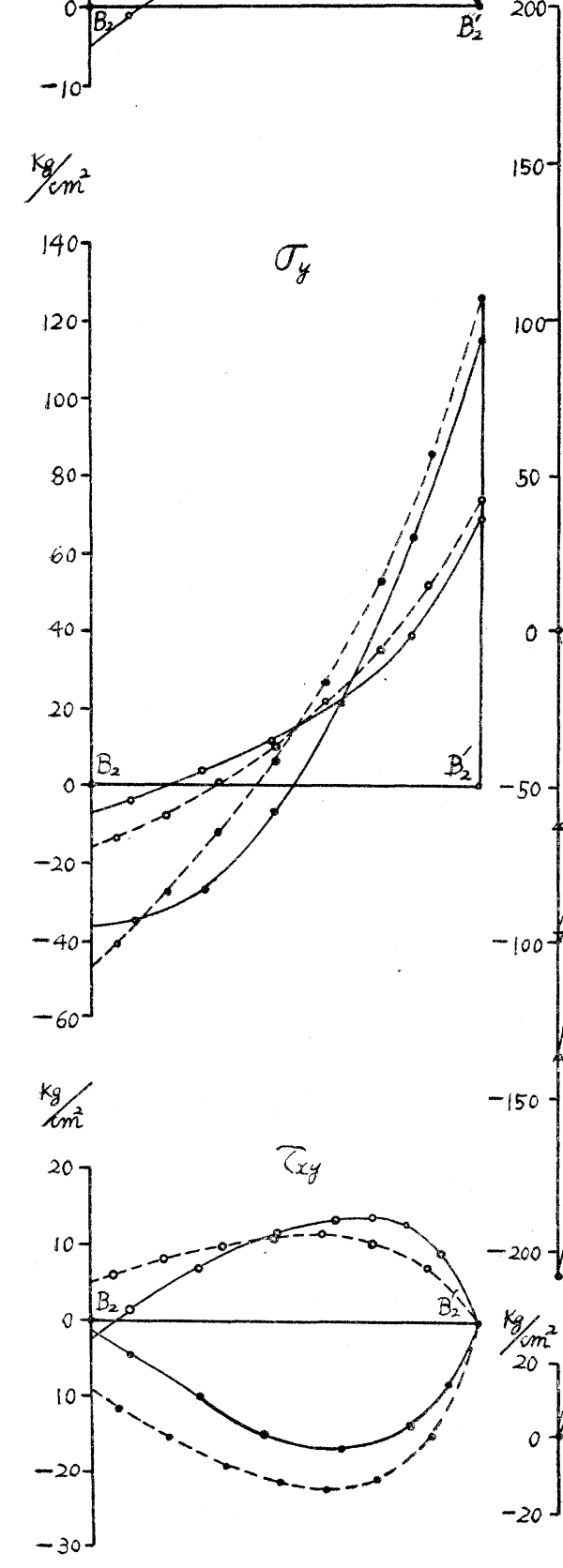
図-7

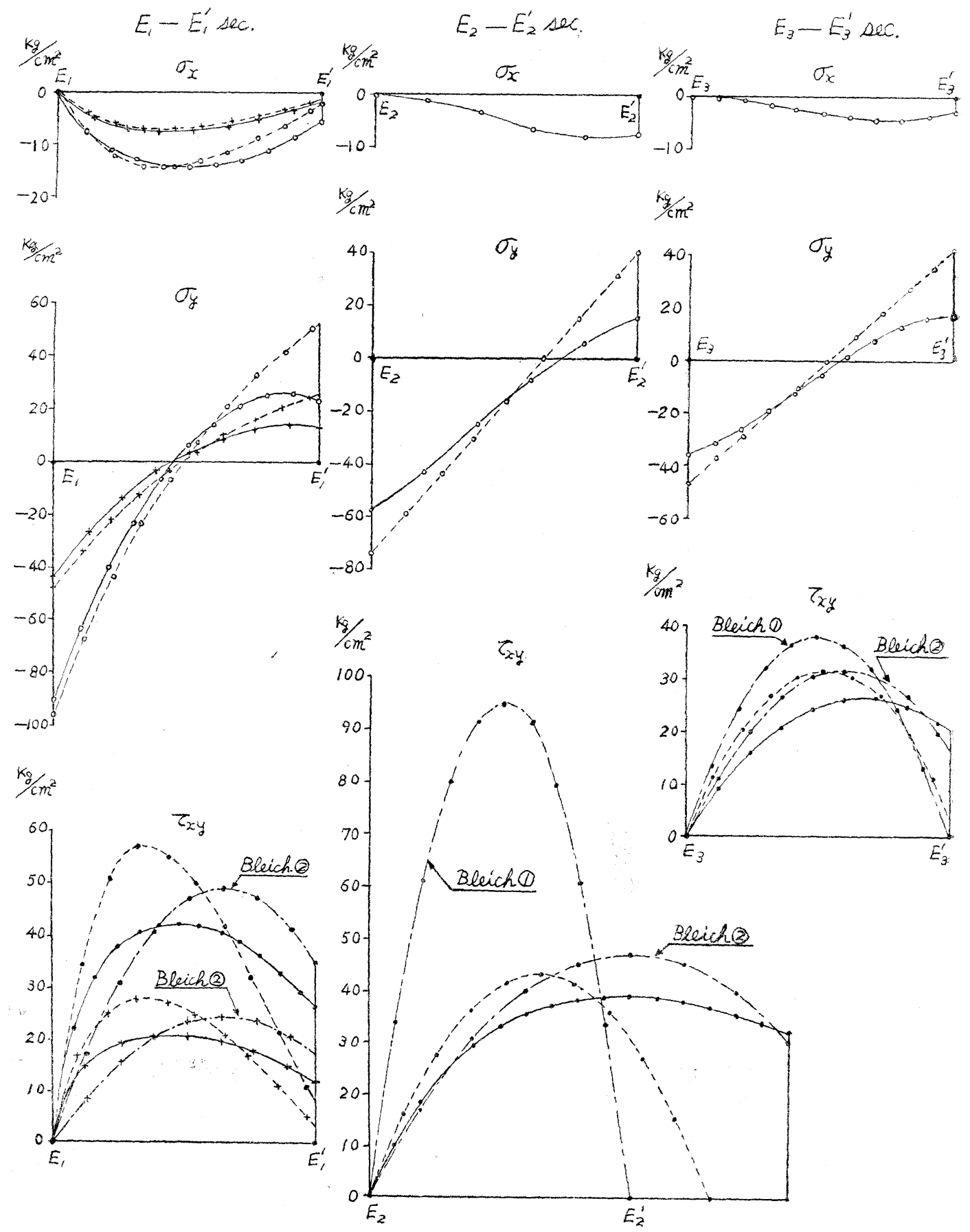




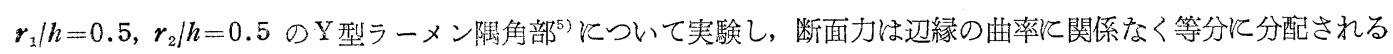
という結論をえた。これはなた C-C'断面にも適用される。したがつて一般的にかかる断面の応力分布は断面力 を2等分し，それらがこの断面に接続すると考党られる曲梁㳊各作用するとして公式から計算した応力の和を求

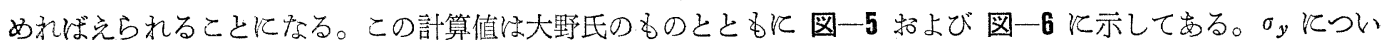
ては筆者の計算は非常によい精度をもつている。しかし $\tau_{x y}, \sigma_{x}$ はその大きさが $\sigma_{y}$ に比して小さいとはい光，い ずれも近似度がよくない。これは直梁の応力分布から，近似的にみて曲梁の応力分布に移る過渡的な断面のため 飞，局部的飞発生する応力によると考光られる7゙。

(2) B-B'，D-D' 断面 F. Bleich 氏はこの断面の計算法にはふれ ず，大野氏は $\mathrm{L}$ 型ラーメンと同じく $h+r(1-\cos \theta) *$ のハリ高を持つ曲

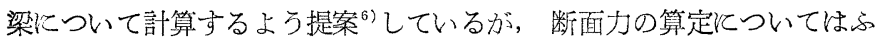
れていない。筆者もラーメン隅角部内の断面の応力計算では断面を補足 すべきであると佮光大野氏の提案を踏襲することにする。しかし $\mathrm{T}$ 型う

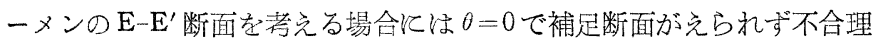

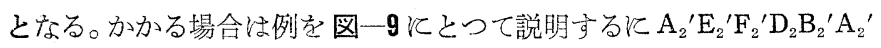
を補足して考学ればよいことがわかつた。そこで補足断面のとり方に更

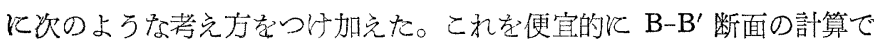
説明する。

図一8を参照して一方では $h+r(1-\cos \theta)$ のハリ高の曲梁 $\mathrm{A}_{1}{ }^{\prime \prime} \mathrm{I}_{1} \mathrm{~J}_{1}$ $\mathrm{K}_{1} \mathrm{C}_{1}{ }^{\prime \prime} \mathrm{C}_{1}{ }^{\prime} \mathrm{B}_{1}{ }^{\prime} \mathrm{A}_{1}{ }^{\prime} \mathrm{A}_{1}{ }^{\prime \prime}$ を考光ると同時《他方では隅角部の緑 $\mathrm{A}_{1} \mathrm{E}_{1} \mathrm{~F}_{1}$ 物よ び $\mathrm{C}_{1} \mathrm{D}_{1} \mathrm{~F}_{1}^{\prime}$ の中点 $\mathrm{E}_{1}, \mathrm{D}_{1}$ を結び, これ接するような緑 $\widehat{\mathrm{A}_{1}{ }^{\prime} \mathrm{B}_{1}{ }^{\prime} \mathrm{C}_{1}{ }^{\prime}}$ の 同心円でかぎられた曲梁を考光る。そしてこれら 2 つの曲梁の外縁のう ち外側にある方が近似計算に使う曲梁の外縁であるとする。図では前者 飞対応する $\mathrm{I}_{1} \mathrm{~J}_{1} \mathrm{~K}_{1}$ がこれにあたる。次にかくして決定された弧接す る $\overline{\mathrm{D}_{1} \mathrm{E}_{1}}$ の平行線を引き隅角部の縁との交点を $\mathrm{G}_{1}, \mathrm{H}_{1}$ とする。そして $\mathrm{G}_{1}-\mathrm{H}_{1}$ 断面々働〉断面力註図のごとく直梁の応力公式によつてこの断面 上に分布させ, これ定外力とみなして $\mathrm{B}_{1}{ }^{\prime}-\mathrm{J}_{1}$ 断面の断面力を算出し, 曲梁公式から応力分布を求めればよい。T型ラーメン隅角部についても 同様である。図一5 招よび図一6はこの計算法がよい精度をもつことを 示している。

(3) E-E 断面 E-E'断面は縁応力の大きくなる断面であるばかり でなく, 板の厚さを決定する断面で設計上きわめて重要な断面である。

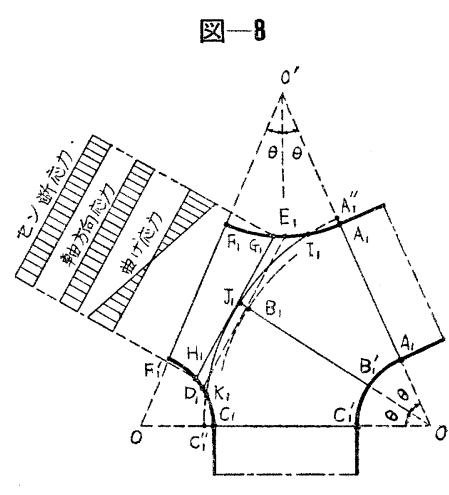

図一9

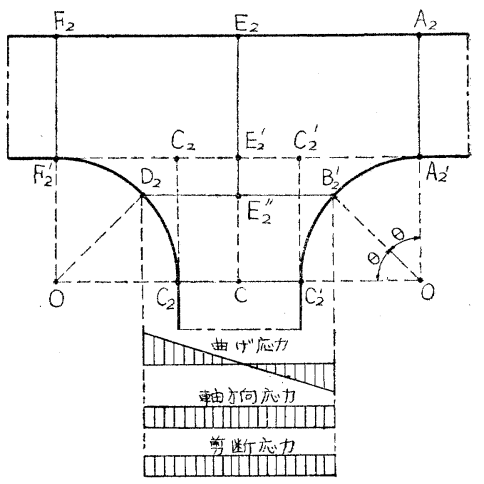

F. Bleich 氏がその書著で扱つている計算法も主にこの断面のセン断応力伛むるものである。T型ラーメン隅 角部はY 型ラーメン隅角部の特殊な場合と考兄られるが，氏怯てれを区別して取报つている。そこで氏の考方方

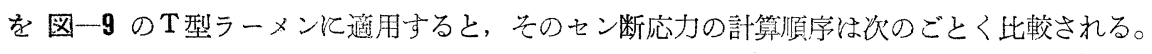

\begin{tabular}{|c|c|c|c|}
\hline \multicolumn{2}{|r|}{ フィンンデール桁節点の計算法 ${ }^{1)}$ *i } & \multicolumn{2}{|r|}{ 多径間ラーメン中間節点の計算法 ${ }^{2)}{ }^{2} 2$} \\
\hline (a) & $\begin{array}{l}\mathrm{A}_{2}{ }^{\prime}-\mathrm{F}_{2}{ }^{\prime} \text { 断面の断面力が } \mathrm{C}_{2} \mathrm{CC}_{2}{ }^{\prime} \text { 断面の直梁 } \\
\text { と作用するとして応力を求め, これを } \mathrm{C}_{2} \mathrm{CC}_{2}{ }^{\prime} \\
\text { 断面の } \mathrm{A}_{2}{ }^{\prime}-\mathrm{F}_{2}{ }^{\prime} \text { 面への投影 } \mathrm{C}_{2} \mathrm{E}_{2}{ }^{\prime} \mathrm{C}_{2}{ }^{\prime} \text { 上飞分 } \\
\text { 布する外力とみなして } \mathrm{E}_{2}-\mathrm{E}_{2}{ }^{\prime} \text { 断面の断面力 } \\
\text { を算出し, } \\
\text { 直梁公式でこの断面のセン断応力を求める。 }\end{array}$ & (a) & $\begin{array}{l}\mathrm{C}_{2} \mathrm{CC}_{2}{ }^{\prime} \text { 断面に直梁公式による応力分有を考 } \\
\text { 兄, これを外力とみなして } \mathrm{E}_{2}-\mathrm{C} \text { 断面の断面 } \\
\text { 力を算出し, } \\
\text { 直梁公式でこの断面のセン断応力龙める } \\
\text { (公式は曲梁公式の特別な場合として使用し } \\
\text { ているのではない)。 }\end{array}$ \\
\hline
\end{tabular}

かくのごとく断面のとり方䄈よび応力公式の利用法に統一がみられない。そこで筹者はここねも前項で説明した 方法を提案したい。これを図一ので説明する。 $\theta=0$ のため置換すべき曲梁 (直梁) の外縁は $\mathrm{B}_{2}{ }^{\prime}-\mathrm{D}_{2}$ で， $\mathrm{B}_{2}{ }^{\prime}-\mathrm{D}_{2}$ 断 面に㗢く断面力を図のごとく直梁の公式によつてこの断面上に分布させ， これを外力とみなして $\mathrm{E}_{2}-\mathrm{E}_{2}{ }^{\prime \prime}$ 断面の断 面力を算出し，直梁公式（曲梁公式の特別な場合として）から応力分布を求める。

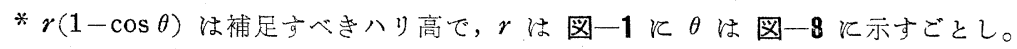

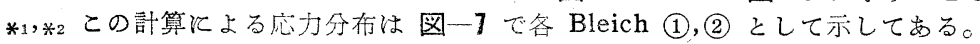


図-7 にはこれら 3 方法による計算応力が示されている。Bleich 氏の多径間ラーメンの中間節点に関する計算 法も結果的には実験結果をよく説明しているようにみえる。

5. 結言

矩形断面をるつ多径間ラーメン隅角部の実験から，この種の隅角部の応力計算には曲梁公式を利用した上記の 方法が合理的であることを知つた。として計算応力は一般飞安全側离るから，この計算法は設計にも利用でき よう。しかしI型断面をるつ隅刍部の計算については推定の域をでない。更に研究を進めて確訨をえたいと考兄 ている。

\section{参考文 献}

1) F. Bleich: Theorie und Berechnung der eisernen Brücken s. $506 \sim 510$.

2) F. Bleich: 鉄骨構造 下巻, pp. 703 70s.

3) I. Ono: Formula for stress of curved beam Memo. of Fac. of Tech. Tokyo Met. Univ. No. 4, 1954.

4) 大野 諌, 山本 稔：ラーメン隅角部の灾用分布の光弾性的研究, 土木学会年次講演会にて発表, 1954 年 5 月

5) M. Yamamoto and H. Inoue: Distribution and Calculation of Stress in Corner of Y-type Rigid Frame Memo. of Fac. of Tech. Tokyo Met. Univ. No. 8, 1958.

6) 大野 諌：鋼ラーメン隅角部及び節点の構造と計算に対する諸注意, 道路, 1954 年 7 月

7) I. Ono: Stress Distribution in Comer of Rigid Frame Proc. of the 4th Jap. Nat. Congr. App. Mech. 1954.

(昭. 33. 8. 26) 